\title{
Unilaterally removing implicit subsidies for maritime fuels
}

\section{A mechanism to unilaterally tax maritime emissions while satisfying extraterritoriality, tax competition and political constraints}

\author{
Dirk Heine $e^{1,2,3,5} \cdot$ Susanne Gäde $^{4}$
}

Published online: 2 February 2018

(C) The Author(s) 2018. This article is an open access publication

\begin{abstract}
Many academics and policymakers agree that implicit tax subsidies for maritime fuels — which are currently granted around the world — are inefficient, but that their abolishment requires a unanimous international agreement. Such an agreement is deemed indispensable because any unilateral action would be impossible due to massive tax competition in this industry, competitiveness effects and the legal limits on regulating an industry operating mostly in international waters, thus outside of any state's jurisdiction. However, an international agreement to solve these problems has proven impossible to reach, thus resulting in the conservation of the status quo. To break this deadlock, we propose a mechanism whereby a small coalition of countries, to start with, can abolish these implicit tax subsidies even in the
\end{abstract}

We thank participants at the EEFS 2015 Conference for comments that greatly improved the manuscript. We furthermore want to gratefully acknowledge financial support from Transport \& Environment.

Dirk Heine

dheine@posteo.de

Susanne Gäde

susanne-gaede@okeanos.me

1 Rotterdam Institute of Law and Economics, Erasmus University Rotterdam, Rotterdam, Netherlands

2 Institute of Law and Economics, University of Hamburg, Hamburg, Germany

3 Faculty of Economics, University of Bologna, Bologna, Italy

4 Department of Business Administration and Economics, University of Duisburg-Essen, Essen, Germany

5 Hoover Chair of Economic and Social Ethics, Université catholique de Louvain, Louvain-la-Neuve, Belgium 
absence of an international agreement. This incentive-compatible scheme solves the above-mentioned issues. The mechanism is furthermore designed to avoid locking in a sub-global scheme. Instead, it has the potential to contribute to unlocking the gridlock in negotiations over a global agreement on this matter.

Keywords Carbon taxation · Maritime emissions $\cdot$ Regional action · International agreements · Tax competition

JEL classification $\mathrm{H} 23 \cdot \mathrm{H} 87 \cdot \mathrm{K} 33 \cdot \mathrm{K} 34 \cdot \mathrm{Q} 54 \cdot \mathrm{Q} 58$

\section{Introduction}

To mitigate climate change, large reductions in global greenhouse gas (GHG) emissions are required. Emissions from the maritime sector, however, are rising fast. International maritime transport accounted for just $2.2 \%$ of global $\mathrm{CO}_{2}$ emissions in 2012 and $2.1 \%$ of global GHG emissions ${ }^{1}$ on a $\mathrm{CO}_{2}$ equivalent basis $\left(\mathrm{CO}_{2}^{e}\right)$. But as trade volumes grow, these emissions are projected to rise by $50-250 \%$ by 2050 , depending on future economic and energy market developments (IMO 2014). In a business-as-usual scenario, maritime transport is expected to account for as much as $17 \%$ of global $\mathrm{CO}_{2}$ emissions by 2050 (Cames et al. 2015). There is an enormous potential for maritime emissions reduction that has not yet been exploited, though. Compared to the baseline scenario, combined technical and operational measures could reduce $\mathrm{CO}_{2}$ emissions by 60-75\% per tonne-kilometre by 2050 (Sims et al. 2014; European Commission 2013).

Yet, to date, despite agreement amongst global governance institutions about the need to tackle the issue ${ }^{2}$ and IEA (2011) and Keen et al. (2011) having called for action at the request of G20 Finance Ministers, there is little market-based policy incentive to improve fuel efficiency. Unlike other transport fuels (except for international aviation), maritime fuels are not subject to fuel excise duties. Nor have emissions from international maritime transport been covered by the Kyoto Protocol, ${ }^{3}$ the Paris Agreement or other international environmental agreements. ${ }^{4}$

Consequently, the negative environmental effects of maritime emissions are not internalised. Using official accounting costs per tonne of $\mathrm{CO}_{2}^{e}$ endorsed by the governments of the United States, Great Britain and Germany, the external cost of carbon

\footnotetext{
${ }^{1} \mathrm{GHG}$ considered for this estimate are $\mathrm{CO}_{2}, \mathrm{CH}_{4}$ and $\mathrm{N}_{2} \mathrm{O}$.

${ }^{2}$ See the register of proposals made in negotiations at the International Maritime Organisation at http://www.imo.org/en/OurWork/Environment/PollutionPrevention/AirPollution/Pages/Market-Based-Me asures.aspx

${ }^{3}$ Bunker fuels are excluded by Art. 2 II, Kyoto Protocol. This has been justified with perceived difficulties in allocating responsibility for emissions released in international waters to individual Kyoto parties (although these emissions accounting problems can be solved, see Heine (2017)).

${ }^{4} \mathrm{GHG}$ emissions from maritime transport have been subject to negotiations in law-making bodies (UNFCCC's working groups SBSTA and AWG-LCA, the Ad Hoc Working Group on the Durban Platform for Enhanced Action (ADP) that is in charge of the issue since 2011 under the UNFCCC umbrella, and the IMO) but no treaty limiting these emissions has evolved.
} 
emitted by this sector in 2012 amounts to between USD-2010 33.7bn and 82.6bn. ${ }^{5}$ Regardless of which of these cost estimates comes closest to reality, it becomes evident that producers and consumers of maritime fuels impose a large external cost on third parties. These third parties are forced to make transfers to the former, and thus implicitly provide them with a subsidy (Stiglitz 2006; Coady et al. 2016). Such a subsidy is conventionally called an implicit tax subsidy or a tax expenditure, i.e. a foregone tax revenue, reflecting the failure of fiscal policy to compensate for the unpriced externality by an emissions tax of equivalent size.

In this paper we suggest an economically and legally viable way to remove implicit tax subsidies for carbon emissions ${ }^{6}$ released by maritime transport in the absence of an international agreement on this issue. In doing so, we focus on a coalition formed by the member states of the European Union (EU), although the mechanism is applicable more widely. In particular, it would work even more effectively in Australia and Japan given their lack of land connections to other jurisdictions. The mechanism we propose would also impose only a small additional administrative burden on tax subjects and authorities by drawing on existing institutions and databases. This paper is also a contribution to finding a way of extending the Paris Agreement's focus on bottom-up national and regional action to a sector where this approach has proven particularly difficult to implement given the international nature of maritime emissions. Lastly, this paper is a practical policy contribution to the literature on negotiation strategy. Oberthür (2003) defends unilateral action (or the threat of unilateral action) as one of the ways to move beyond political stalemate with regards to maritime emissions. In this article, we provide a sector example of how regional action may enable global cooperation, instead of harming it.

The paper is structured as follows: Section 2 reviews the previous literature on unilateral schemes for pricing emissions in the maritime sector. Section 3 introduces the emissions tax regime. It first elaborates on what the appropriate tax bases should be for international and intra-EU shipping, by whom the tax should be paid, and how the tax base could be computed. Subsequently, it expands on why using two different tax bases is unproblematic, and how the tax rate should be set. Section 4 concludes.

\section{Related literature}

To increase social welfare, Pigou (1932) suggests that external social costs inflicted by the private sector can be interalised by levying a corrective tax on the activites that cause the damage. In the case of climate change mitigation, an equivalent effect can be obtained with other market-based mechanisms (MBM) such as emissions trading if they impose the same carbon price per unit of emissions. When applied to emissions released in the international maritime sector, the Pigouvian theory encounters

\footnotetext{
${ }^{5}$ These estimates follow from multiplying the total amount of maritime emissions from IMO (2014) with the US Cost of Carbon (US-IAWG 2013), the UK Treasury's Shadow Price of Carbon (Price et al. 2007) and the German mid-level, short-term estimate of the external cost of carbon (Burger 2014; Schwermer 2012; Friedrich et al. 2007).

${ }^{6}$ The concept can be easily extended to other pollutants, too, once the data is raised by EU authorities.
} 
various obstacles, though. Many authors have agreed on the need to cap maritime emissions but at the same time have expressed various feasibility concerns.

Since most maritime emissions occur in international waters, taxation by single states may be legally infeasible. Due to legal prohibitions of extraterritoriality, i.e. the legal limit on a country's ability to impose obligations (such as a tax) outside its own jurisdiction (Scott 2014), each country might only be allowed to charge for emissions arising in its internal waters. However, such a narrow tax base would leave almost all of the maritime sector emissions uncovered (Faber et al. 2009; Bäuerle et al. 2010), and thus severely limit the environmental effectiveness of the tax.

Due to the mobility of sea trade, taxation might furthermore also be economically infeasible. There is already severe competition in taxes on shipping activities, and concerns are that maritime emissions taxes could be avoided by moving to tax havens (e.g. Keen et al. 2013). Furthermore, a maritime emissions tax might be infeasible if trade patterns are to be safeguarded from distortions (e.g. Keen et al. 2011). All these concerns have led to the conclusion that taxation of maritime emissions may only be feasible through a unanimous international agreement. Yet, whilst taxation by individual jurisdictions has been deemed legally and economically infeasible, taxation through a unanimous international agreement appears politically infeasible. Due to incompatibility of views, for instance between island states and oil producing countries, such unanimity is utopian. Consequently, with some important exceptions, ${ }^{7}$ years of negotiations within the IMO and the G20 on carbon pricing in maritime transport have produced no tangible progress. This gridlock is symptomatic for negotiations on climate change mitigation in general where any reluctant party can bring the whole process to a halt because on a global level unanimity is required for reaching an agreement.

Economic contract theory suggests that parties negotiating a global climate agreement will block the introduction of an emissions tax in case it reduces their payoff relative to their reference point, i.e. the non-cooperative alternative. For negotiations requiring unanimous agreement, the reference point equals the status quo, as parties know that without their consent no deviation from the status quo is possible. This gridlock may be unsettled if at least one party is able to threaten to set up a unilateral tax scheme - which requires such a tax scheme to be effective and its implementation to be feasible. After such a unilateral scheme will have been introduced, those parties that are currently blocking a global agreement will need to re-evaluate their stance towards a global tax regime; but this time vis-à-vis the payoff they realise as outsiders faced with the effects of a policy unilaterally implemented by another negotiation party. Ironically, it is the introduction of a unilateral tax regime that could then

\footnotetext{
${ }^{7}$ At the beginning of 2013, amendments to the International Convention for the Prevention of Pollution from Ships (1973) and Protocol (1978) (hereafter MARPOL) Annex VI Regulations to improve the energy efficiency of vessels came into force. This was an important step by the International Maritime Organisation (IMO) in order to target emissions released by maritime transport, though on their own, these policies do not set dynamic incentives to reduce emissions. These regulations tackle network externality problems and foster R\&D in the sector. However, they do not affect marginal incentives to optimise fuel consumption.
} 
render a unanimous agreement possible. This is because the existence of a feasible unilateral tax scheme improves the outside option of those in favour of a global emissions tax, whilst simultaneously changing the reference point for those blocking it: If its negative effects on the non-cooperative payoffs are large enough, unilateral action will make the outsider willing to engage in a global agreement, thus overcoming the current stalemate. More details on the potential impact on negotiations are provided by Heine et al. (2017b).

Kollamthodi et al. (2013) find that unilateral MBM can be used to sucessfully reduce emissions from maritime transport - without recommending any specific instrument, though. They suggest that any exact tracking of released GHG emissions and of other relevant data would carry a high administrative burden. Faber et al. (2009) analyse an emissions tax that covers shipping in EU waters. According to this proposal, the scope of emissions covered by the tax varies by whether the incoming vessel carries a single Bill of Lading (i.e. all cargo shipped shares both the same port of origin and the same port of destination) or multiple Bills of Lading (i.e., the vessel carries cargo with different ports of origin and/or ports of destination). The authors recommend that the tax bill be determined per vessel. This implies that the vessel owner is taxed only for the emissions released on the last leg of the cargo transport into the EU, as emissions of other ships prior to transshipment taking place outside EU waters cannot be considered. As a result, Faber et al. (2009) find that this scheme provides opportunities for tax avoidance, however to a limited extent. The emissions coverage is further reduced by the proposed introduction of size thresholds: The authors recommend that the tax be based on data from emissions measurements executed by each vessel. As this is considered costly for small ships, those would be exempted from the tax.

Both Hemmings (2011) and Kågeson (2009) recommend taxing maritime emissions through a fuel tax, but recognise that, for international shipping, unilateral fuel taxation causes too much base erosion as vessels could refuel easily outside the geographical coverage. Therefore, they hold that international shipping should be exempted, at least temporarily, from the tax. Like Faber et al. (2009) and Kollamthodi et al. (2013), they recommend that the tax bill be determined per vessel. In the medium-term, Kågeson (2011) envisions a gradual increase of the regional coverage of the emissions tax, extending it to the last leg of incoming voyages and the first leg of outgoing voyages, similar to the proposal in Faber et al. (2009). In the case of multiple Bills of Lading where the cargo composition varies during the voyage, he suggests calculating the emissions for the route over which the majority of the goods destined for the EU was transported. Shipping lines therefore would be able to reduce their tax liability somewhat through varying the location of transshipments and the composition of their cargo.

Bäuerle et al. (2010) analyse the calculation of maritime emissions based on the total distance over which cargo has been transported to (from) the EU as one of three options to integrate maritime emissions into the EU ETS. The necessary data can be retrieved, amongst others, from customs databases. Total emissions, however, are not calculated from actual data but based on vessel and trade lane specific average values. The authors highlight that the suggested tax regime does not establish a link between cargo consignees (consignors) and vessel owners, which puts a question mark on the 
environmental effectiveness of the tax. Overall, Bäuerle et al. (2010) conclude that this option may not be sufficiently exact to serve as carbon pricing method.

\section{Policy design}

In the following, we will present a regional Pigouvian tax scheme on emissions from maritime shipping, i.e. a price-based mechanism internalising the present value of marginal future climate damages caused by these emissions. We will discuss the main features of the tax scheme by expanding on the appropriate tax base, the definition of the legal tax liability and the recommended tax rate. In doing so, we build upon the strengths of the above-discussed strand of literature whilst sketching a tax regime that both reduces the opportunities for tax avoidance and solves extraterritoriality issues usually occurring with unilateral taxation. Furthermore, we present new arguments on the effects of the schemes established in the literature referred to above. The tax scheme presented below consists of two different regimes for emissions released in both international shipping (Sections 3.1-3.3) and intra-EU shipping (Section 3.4). To be effective, both regimes should be put in place jointly and by the EU as a whole.

\subsection{Choosing the right tax base for international shipping}

Determining the tax base requires defining both the taxable activity and the geographical coverage of the emissions tax. We will also elucidate the treatment of transshipment and transit under the tax.

Taxable activity The choice of the taxable activity should be made based on which option allows the internalisation of the greatest share of the external social cost of the emissions at the lowest policy cost (Demsetz 1967). Literature suggests, strictly under the condition that the policy is applied globally, that a tax on maritime fuel consumption would be the first-best option for internalising climate damage from carbon emissions: The own-price elasticity of maritime fuels is rather low (Keen et al. 2011, 2013; Mazraati 2011). Thus, demand for maritime fuels can be expected to only slightly decrease as a reaction to the introduction of a global tax on maritime fuels. In addition, because of the low elasticity of cargo demand, the increase in the fuel price triggered by the tax will have a high pass-through to the purchaser of the freight services (Keen et al. 2013), thus limiting the commercial impact of the tax on shipping companies. As a result, introducing a tax on maritime fuel consumption is an effective policy to price carbon emissions if - and only if - the policy is implemented via an international agreement with global coverage.

The success of introducing a tax exclusively in one region, however, depends on the cross-price elasticity of demand for maritime fuels in that region relative to maritime fuel prices in regions outside the tax regime. This elasticity is much higher because, to avoid the tax, vessels navigating in several jurisdictions can refuel en route in a port not included in the tax scheme or in international waters (e.g. from tankships or floating platforms). Consequently, in the absence of a global agreement 
unilateral fuel taxation would cause too much tax base erosion. Many argue that these avoidance opportunities render regional taxation of maritime emissions infeasible (e.g. Mishra and Yeh 2011; Keen et al. 2011, 2013; Heitmann and Khalilian 2011; Miola et al. 2011). Indeed, an attempt to introduce a maritime fuel tax in Port of Long Beach/California has failed (Mishra and Yeh 2011) and ever since served as a striking counter-argument against unilateral taxation of maritime fuels.

Consequently, if a unilateral EU tax on maritime transport emissions was introduced, internationally mobile deep-sea vessels should not be charged based on their fuel uplifts within the EU. Instead, the appropriate tax base still covers the total emissions but circumvents the issue of tax avoidance which results in carbon leakage. ${ }^{8}$ Whilst the cross-price elasticity of demand for refuelling internationally mobile vessels within the EU is too high for fuel consumption to serve as a sound tax base in the case of unilateral action, the elasticity of demand for the service of lading and unlading cargo 9 in the EU is much lower. As transshipment is irrelevant for customs purposes, any transfer of cargo from a vessel to a mode of inland transport or vice versa in a port just outside the EU (e.g. in St Petersburg or Ambarl1/Istanbul) would not result in an exemption from the emissions tax. Although this method might in certain cases - albeit only slightly - reduce the overall tax burden, it would be irrelevant since the cost advantage of maritime transport over land transport is considerable. Another possible vehicle for tax avoidance would be to ship intermediate products to a port close to the EU for final assembly and then ship the final products to the EU (with regard to imports) or the foreign destination (with regard to exports), replacing the direct shipment of final products. Then the emissions tax would be charged only for the short distance between the EU port and the closeby non-EU port, thus massively reducing the tax burden. However, this would likely be discouraged by the cost of shifting production and the potentially substantially higher duty burden due the fact that both the intermediate and the final products would be subject to import and export duties (if applicable) in the customs areas concerned.

Treatment of transshipment and transit Taxing emissions without risking base erosion and a decline in the competitiveness of EU ports mandates an exemption for transshipment - the act of shipping cargo to a hub port for onwards shipment to a destination port - and for transit - the act of transporting cargo via the EU to third countries without releasing the cargo into free circulation in the EU. One reason for mandating these exemptions is that the implementation of an EU emissions tax must not discourage other countries from for their part putting in place an emissions tax. If emissions taxes were levied on several legs of a transportation chain, taxation would likely become complex, hence increasing transaction costs markedly. Second, in contrast to the elasticity of demand for loading (discharging) cargo at source (destination) ports, the elasticity of demand for transshipment and transit services is high. Thus, whilst in most cases it is commercially unviable to substitute EU destination ports with non-EU destination ports, this may not hold for transhipment and transit

\footnotetext{
${ }^{8}$ Carbon leakage describes a situation in which reducing emissions in one region is (partially) offset by an increase in emissions in another region. See Kollamthodi et al. (2013) for an in-depth analysis of this issue. ${ }^{9}$ In the remainder of the text we use the term cargo as a collective term for both containers and bulk cargo.
} 
services. For global shipping companies, there is more flexibility in the location of transhipment as opposed to destination ports. Hence without an exemption of transhipment and transit in place, an EU emissions tax could both distort transhipment and transit patterns and constitute a comparative disadvantage for EU ports.

Exempting transshipped cargo is administratively simple. Transshipped cargo does not clear customs, so if the emissions tax is levied at the point of customs clearance, transshipped cargo will be excluded from the process anyway. Furthermore, the transshipment status of products is already documented in the existing customs systems. Exempting cargo in transit is similarly straightforward. Cargo designated for transit is treated separately by customs already, with automated tracking and control in place (in form of the EU's electronic transit system NCTS). Exempting cargo designated for transit from the emissions tax would hence be highly automatable and not require extensive new tax administration or rule compliance processes, thus limiting the transaction costs of the proposed measure.

Geographical coverage Faber et al. (2009), Kågeson (2011) and Kollamthodi et al. (2013) argue that, due to data unavailability, any unilateral emissions tax should only cover emissions released on the last inbound or first outbound leg. We instead argue that emissions released during the whole voyage should be subject to the tax.

First, it is not rare that ships change their port of destination after having left their port of origin. En route shifts in the port destination can occur, for instance, because of changes in cargo purchasers. For this reason, limiting the taxation coverage to the first outbound voyage could be problematic, as it allows tax avoidance behaviour via artificial en route destination shifts. Second, taxing emissions from the last inbound or first outbound leg only would provide an incentive for shipping companies to have cargo transshipped or at a port outside of EU waters, causing a significant loss of tax revenue (Faber et al. 2007). ${ }^{10}$ The costs of transshipment might not outweigh the tax savings in all cases, but on the margin trade lanes would be distorted, environmental effectiveness compromised and tax revenues reduced. Third, transshipment would come at a cost to shipping companies, thus raising the cost of trade. The overall cost of maritime transport would therefore rise by more than the emissions tax itself suggests. Fourth, for each cargo item the country of origin needs to be documented by a country of origin certificate (Art. 23 and 24 Community Customs Code) and is recorded in customs databases. If no country of origin certificate is presented, however, the port of departure can be assumed indicative for the country of origin until no other information is made available. Using customs data to estimate the provisional tax base therefore requires extending the coverage of the tax to the whole voyage. A fourth argument in favour of including the emissions released on the whole voyage is that the positive impact of the tax regime on international climate negotiations would be much stronger. If the emissions tax is levied on the last inbound and first outbound leg only, non-EU transshipment ports in general and non-EU transshipment ports located close to the EU in particular could raise their market shares. As a result,

\footnotetext{
${ }^{10}$ For example, if a previously non-stop shipment from Tokyo to Rotterdam now included transshipment in Singapore, the tax liability could be reduced by $26 \%$ (comparing the respective distances along the standard trade lanes using data from www.sea-distances.org).
} 
the countries hosting these ports would likely prefer the unilateral EU scheme over an international or global one and thus block negotiations on international alternatives. The same arguments hold against the option of taxing emissions from all ship movements within territorial waters of the EU only. The above mentioned issues would even be aggravated under such a scheme. For all these reasons, it is important that the geographical coverage of the tax is not restricted to the last inbound or first outbound segment or to intra-EU voyages. In the following, we explain how the regional tax regime can have a global coverage.

\subsection{Defining the legal tax liability for international shipping}

Authors advocating for restricting the geographical scope of the tax to the last inbound leg of a voyage (Faber et al. 2009; Kågeson 2011; Kollamthodi et al. 2013) or even only to voyages within EU waters (short-run policy favoured by Kågeson (2011)), also recommend the ship owner as taxable entity and the vessel as accounting unit for the determination of the tax liability. We argue that these two recommendations are interdependent. The ship owner being the taxable entity implies necessarily that the vessel has to be the corresponding accounting unit. From that it results that only the emissions released by the very vessel calling at the first EU port can be considered for the computation of the outstanding tax. Compromising the efficient use of this method, many cargo items are transshipped en route. Consequently, the vessel that transports cargo from the last transshipment port to the first EU port accounts for just part of the emissions that were released en route to the EU. The impact of this fact is relatively insignificant in bulk transport where transshipment is rare, but large in container transport.

If, however, total emissions are to be covered under the tax regime, the emissions released by the previous vessels in the transport chain also need to be included. But this requires refraining from treating the vessel as the accounting unit and its owner as the taxable entity. Otherwise, tax authorities would need to charge the owner of the last vessel for emissions that were released by vessels owned by other entities. Such a tax appears to lack a legitimate basis.

Instead, the tax subject should be an agent who remains involved throughout the whole transport chain, irrespective of transshipment. The consignee of the cargo for imports and the consignor of the cargo for exports meet this requirement. The accounting unit that matches the consignee (consignor) is the unit of cargo. This solves the problem of how to tax total emissions in cases where vessels carry cargo from various ports of origin (destination) - i.e. the problem of multiple Bills of Lading that are considered potential sources of tax avoidance by Faber et al. (2009) and Kågeson (2011). Within this framework, the effective tax rate would not vary in the composition of the cargo origins or destinations, as every consignee (consignor) would pay for the emissions released on the whole route from the source port to the destination port of the cargo.

Defining the consignee (consignor) as the taxable entity has both legal and political advantages, too. According to the Community Customs Code, the consignee (consignor) of cargo imported into (exported from) the EU must always be entities incorporated or resident in an EU member state. Ship owners, by contrast, can be 
incorporated anywhere in the world. If ship owners were the taxable entity, the tax liability would hence often fall on foreigners, causing political and potentially also legal concerns related to the state jurisdiction over foreign vessels in international waters (Dominioni et al. 2018). Given that most emissions are released in international waters, states need a solution to efficiently price the emissions at their source, whilst at the same time complying with their jurisdictional limits.

Extraterritoriality concerns arise if a state is directly involved in imposing obligations outside its own jurisdiction. But unlike public law, cost sharing through contract law does not end at national borders. Private parties negotiating their prices will take into account the tax-induced cost increase. Therefore, when domestic consignees (consignors) are charged an emissions tax, they will generally pass on some of the tax burden to the other parties involved, irrespective of where the latter are incorporated. The portion of the tax burden being passed on depends on the relative elasticities of demand and supply, and the market structure along the supply chain (Keen et al. 2011). From this it follows that the share of the economic tax burden born by each party involved is independent of the allocation of the legal tax liability (Jenkin 1871; Logue and Slemrod 2010). Situating the legal tax liability for imported (exported) products with the domestic consignee (consignor) hence avoids extraterritoriality constraints. Simultaneously, the political resistance from non-EU states against a unilateral EU carbon pricing scheme - which e.g. hampered the introduction of the EU-ETS for aviation emissions - could be overcome. This is because only EU residents would be subject to the maritime emissions tax.

\subsection{Determining the tax base for international shipping}

The computation of the tax base requires detailed knowledge of the levels of emissions released, which is a general concern regarding the implementation of environmental taxes. In their own jurisdiction, governments are free to impose regulations that force polluters to provide the data, e.g. through the installation of monitoring equipment. But in the case of maritime emissions taxes, jurisdictional restrictions apply (Wilensky 2014). These jurisdictional limits prevent tax authorities from imposing control systems on foreign ships. A national law stipulating that ships entering a jurisdiction's internal waters need to have a special monitoring equipment installed seems to solve the problem (Faber et al. 2009). But even such port access standards could only extend to the last one or two legs of an international itinary. Thus, we suggest combining taxation on default values with granting subsidies if actual emissions are proven to have remained below these default values.

Typification Taxation on default values, also known as typification, is the systematic adaptation of default values for different stylised types of taxpayers. It is frequently used in other fields of tax policy that exhibit severe data constraints (e.g. income taxes). These regimes facilitate organisational learning. Taxpayers are incentivised to provide data on a voluntary basis which is then used by the tax authorities to iteratively refine the default values and make them as realistic as possible. These regimes are justified if the alternative - tax authorities calculating the exact tax liability for each single case and bearing the burden of proof - is too costly. Taxation based on 
default values helps cutting compliance and administration costs. These cost savings, however, are partially offset by a reduction in tax revenue. This loss of tax revenue arises because only those taxpayers who believe that they have been overcharged have an incentive to opt for a favourable tax assessment and will provide the required data. However, there are also those who will not challenge their tax bills because in reality they have emitted more than was assumed or because they do not want to provide any data. As a result, the tax revenues will be lower compared to regimes where the tax liabilities of all taxpayers are determined on a case-by-case basis.

The optimal default values have thus to be determined by weighing the reductions in compliance and administration costs against the loss of tax revenue. This is also a trade-off between environmental effectiveness and the costs of policy. A policymaker who cares most for the maximum environmental effectiveness will set the default value higher, as a greater portion of maritime transport is then affected by dynamic incentives. A policymaker who is willing to somewhat reduce the environmental effectiveness of the tax in favour of lower administration and compliance costs, will instead set a lower default value. And a policymaker who most wants to implement a mechanism whithout causing major disruptions - for example to be able to gradually build up institutional capacity to manage the scheme - would start with a lower default value and then increase it gradually. We favour setting the default values so as to provide incentives such that the environmental effectiveness is high and efficient ships are not discriminated against.

Computation of the tax bill The emissions can be calculated from fuel consumption per type of fuel $\left(w_{\text {fuel }}\right)_{i}$ [tons]. Multiplication with the carbon content $\left(f_{\text {carbon }}\right)_{i}$ [tons of $\mathrm{CO}_{2}$ per tons of fuel] of the fuels used yields the $\mathrm{CO}_{2}$ emissions $e$ [tons of $\mathrm{CO}_{2}$ ] released whilst burning the fuels:

$$
\begin{aligned}
e & =\sum_{i=1}^{n}\left(w_{\text {fuel }}\right)_{i}\left(f_{\text {carbon }}\right)_{i} \\
& =w_{\text {total }} \sum_{i=1}^{n}\left(\theta_{\text {fuel }}\right)_{i}\left(f_{\text {carbon }}\right)_{i},
\end{aligned}
$$

where

$$
\left(\theta_{\text {fuel }}\right)_{i}=\frac{\left(w_{\text {fuel }}\right)_{i}}{w_{\text {total }}}
$$

is the share of fuel type $i$ of total fuel consumption $w_{\text {total }}=\sum_{j=1}^{n}\left(w_{\text {fuel }}\right)_{j}$, and $\sum_{i=1}^{n}\left(\theta_{\text {fuel }}\right)_{i}\left(f_{\text {carbon }}\right)_{i}$ is the average carbon conversion factor for a given vessel.

Fuel consumption can be approximated by multiplying the transport work performed by the vessel with its assumed energy efficiency $\eta^{\mathrm{e}}$ [tons of fuel per ton-kilometre]:

$$
w_{\text {total }} \approx \eta^{\mathrm{e}} d^{\mathrm{e}} w_{\text {cargo }}
$$

Transport work is defined as the weight of cargo transported $w_{\text {cargo }}[\mathrm{t}]$ multiplied by the estimated distance from the cargo's port of origin to the port of destination $d^{\mathrm{e}}[\mathrm{km}]$. There it is crucial to assume that the most direct one of the major trade lanes between the two ports has been taken. The provisional tax bill $T$ can then be 
determined by multiplying the released emissions $e$ with the carbon price $p_{\text {carbon }}$, using equations (1), (2) and (3):

$$
T=\frac{1}{2} p_{\text {carbon }} \eta^{\mathrm{e}} d^{\mathrm{e}} w_{\text {cargo }} \sum_{i=1}^{n}\left(\theta_{\text {fuel }}\right)_{i}^{\mathrm{e}}\left(f_{\text {carbon }}\right)_{i} .
$$

That is, the provisional tax bill is calculated by multiplying the hypothetical direct distance travelled by the weight of the cargo, the assumed vessel efficiency, the assumed emissions factor, and the carbon price. The assumed vessel efficiency includes assumptions on average capacity usage, speed, engine types and other factors. We will expand on the calculation of the default values in the next section. Notice that only half of the incurred climate damage would be taxed because the EU only has a legitimate claim on half of the tax base, whilst for imports (exports) the country of origin (destination) has the right to claim the other half. Thereby no multiple carbon pricing would occur even if other jurisdictions introduced a similar carbon pricing scheme.

If the tax autorities estimate the tax base correctly, the tax will provide the consignee (consignor) with the Pigouvian price signal. If however, the calculation of the tax base was too high because one or more default values did not match the actual values, setting the right Pigouvian price signal requires one further step. To see this, assume that the emissions caused by transporting cargo that either was delivered to a EU-destination or originated in the EU were actually lower than was estimated by the tax autorities. This case is dealt with by allowing the shipping company to optionally provide the tax autorities with data proving that the transport of the cargo actually caused less emissions than initially assumed by the tax autorities. On the provision of such proof, the tax autorities will disburse the excess amount of tax. As already argued, to overcome extraterritoriality constraints it is crucial that the tax subjects are the cargo consignee (for imports) or consignor (for exports). Still, any excess amount of tax should be disbursed to the shipping company. This is because the shipping company has the most detailed information about how the cargo was transported and what amount of emissions was released. Hence the shipping company is able, if applicable, to provide the proof necessary to claim the payout of the excess amount of tax more cheaply than the cargo consignee (consignor).

For the distribution of the net cost of the tax, it is irrelevant that the state offers shipping companies a subsidy and charges cargo consignors (consignees) a tax - the economic incidence of the fiscal payments is not affected by the question to whom a tax or subsidy is remitted. This is because the cargo consignee (consignor) negotiates freight rates with the shipping company, and hence a shipping company that receives a subsidy will have to agree to a lower freight rate. The tax incidence would have been the same had the consignor (consignee) been both charged the tax and refunded the excess amount of tax. The advantage of providing the subsidy to shipping companies is that it overcomes the extraterritoriality problem whilst also making the party with the most detailed information about the emissions released cooperate with the tax autorities. $^{11}$

\footnotetext{
${ }^{11}$ This is a mechanism design different from the more standard use of two-part environmental fiscal instruments in the Environmental Economics literature where the recipient of the tax rebates is the same entity
} 
The amount of the subsidy ${ }^{12} S$ that the shipping company receives is determined as follows:

$$
S=T-\frac{1}{2} p_{\text {carbon }} \eta d w_{\text {cargo }} \sum_{i=1}^{n}\left(\theta_{\text {fuel }}\right)_{i}\left(f_{\text {carbon }}\right)_{i} .
$$

Whereas in the calculation of the tax bill (Eq. 4), $d^{\mathrm{e}}$ is the assumed direct distance between the cargo's port of origin and its port of destination, the distance $d$ is the actual distance sailed by the ship after loading the cargo until offloading it. Equally, $\eta$ in the subsidy refers to actual fuel efficiency per ton-kilometre, which reflects the determinants such as the actual capacity usage of the ship, speed, engine type, weather and other factors, whilst the carbon conversion factor $\sum_{i=1}^{n}\left(\theta_{\text {fuel }}\right)_{i}\left(f_{\text {carbon }}\right)_{i}$ depends on carbon content of the fuel and potential future uses of pollution control equipment such as CCS.

Submitting the data to prove the entitlement to a subsidy is rather straightforward for shipping companies as it is already common industry pratice to calculate $\mathrm{CO}_{2}$ emissions. They are also used to retain their fuel delivery notes which allow for a computation of the emissions released (Business for Social Responsibility 2015). The definition of distance underlying the tax formula is defined such that several shipping companies can claim subsidies on the same piece of cargo whilst each receives only the portion of the excess amount of tax that each ship should rightly claim given its share in transporting the cargo from its port of origin to its port of destination. That is, to be eligible to a subsidy, a shipping company does not need to be the last (first) carrier in the maritime transport chain to the EU port of destination (from the EU port of origin). Instead, it is sufficient for the shipping company to establish that cargo which it has carried for some of the distance has afterwards been imported into the EU (initially been exported from the EU). This way, carriers along the whole maritime transport chain are provided with the incentive to reduce their emissions and submit the relevant emission data to EU tax authorities. Since subsidies are determined based on cargo that has been imported into (exported from) the EU, the calculation of the subsidies is not distorted by the composition of the cargo on board, i.e. no subsidies can be claimed in cases where the cargo has not been imported into (exported from) the EU.

Due to the prospect of obtaining subsidies, shipping companies have an incentive to emit less than the default amount of emissions determined by the tax autorities. Because of the subsidies a shipping company receives, it can offer more competitive freight rates (and as argued above, also has to). Through this process, shipping companies have an incentive to supply the tax autorities with an increasing amount of data. This then enables tax autorities to continously improve the estimation of the provisional tax base. Thus, the tax autorities receive the required data without having

as the tax payer (see Parry et al. 2014; Fullerton and Wolverton 2005). In taxing maritime emissions it is economically efficient and legally important to separate tax payer and recipient of the subsidy or rebate. This can also be beneficial for tax-and-rebate mechanism outside this sector, since the tax liability is shared in the same way in both cases but the legal complications as well as the transaction costs can be reduced through this apportionment.

${ }^{12}$ Technically, the payout of the excess amount of tax is not a refund, but a subsidy. A tax refund would demand the excess amount of tax to be refunded to the tax subject, i.e. the cargo consignee (consignor). 
mandated its provision. In this way, the tax autorities are in a position to levy taxes on precisely quantified emissions even when they lack the legal ability to mandate all taxpayers to report their emissions. They only need to demand that the taxpayers providing the data also grant rights to verify the accuracy of the submissions through random cheques - either by the tax authorities or by authorised independent verification commpanies. ${ }^{13}$ Hence the problem as regards to the tax authorities' limited data access rights is solved. Furthermore, the random checks also incur much less administration costs compared to the case where the tax autorities have to bear the burden of proof.

Computation of the default values In maritime policy debates, it is often claimed that data on maritime emissions is currently too scarce for policy action. Accordingly, both the EU policymakers IMO's Marine Environment Protection Committee seek to first establish regulations for Measurement, Reporting and Verification (MRV) before moving on to the design of mitigation objectives and then policy measures for attaining those objectives (IMO 2015; European Commission 2013). The mechanism described here could help to speed up this process as it would be able to provide efficient mitigation incentives even without mandatory MRV. Instead, MRV would be voluntarily adopted by shipping companies with an interest in receiving the subsidy payment. It is, therefore, unnecessary to wait with the introduction of policy measures until when today's maritime MRV systems will have been harmonised and extended to global coverage. With this policy design, carbon pricing does not require mandatory MRV to function efficiently. In the following, we will show that the datasets required to estimate a sound provisional tax base are or soon will become available to the competent authorities via European electronic data management systems, and without incurring substantial administration cost. Moreover, the tax regime provides incentives for shipping companies to voluntarily provide additional data, which will result in a comprehensive and concise database over time. This will be the case although obtaining direct data about the emissions of ships on a per-voyage basis in international waters is legally and administratively complex.

In the case of ships calling at EU ports, it will become possible to estimate rather precise default values from 2019. From January 2018, the regulation on the monitoring, reporting and verification (MRV) of carbon dioxide emissions from maritime transport ${ }^{14}$ will mandate shipping companies to record (on a per-voyage and annual basis) and report (on an annual basis) audited data on fuel consumption, distance travelled, ship efficiency, and carbon emissions for each ship. Hence detailed data on carbon emissions will become available to the European Commission and the EU member states' competent authorities. The MRV system will cover about 90 cent of the relevant emissions, as vessels below 5,000 gross tonnage (GT) are excluded to reduce the administrative burden.

\footnotetext{
${ }^{13}$ See Heine et al. (2017a) for an analysis how this mechanism can be protected against fraud and how the admistration costs for the processing of subsidies claims and the verification of data submissions can be minimised.

${ }^{14}$ Regulation (EU) 2015/757.
} 
Besides the EU-MRV system, further databases are available to calculate the default values. As also for other cargo import and export notifications have to be submitted, the required information can be retrieved from customs databases, including the weight of cargo, the consignor's and consignee's identities and addresses, the port of origin and the port of destination, as well as stop-overs/transhipments en route. The direct sea lane distance between the port of origin and the port of destination is hence available. ${ }^{15}$ Another data source for computing the default values is AIS positioning data.

This data will be complemented by MRV data of the previous year on the annual average energy efficiency of the given vessel and the annual average carbon conversion factor for this vessel. The customs and MRV datasets can be merged using the IMO Ship Number which is a unique identifier for ships contained in both datasets. This estimation method will incur only low administrative or compliance costs, as each of these data is or will be shared electronically amongst EU competent authorities via joint data management systems.

Regulatory MRV will, however, only cover emissions from vessels calling at EU ports. For the emissions released further upstream and for ships with less than 5,000 GT, the competent authority will have to use alternative, albeit initially less precise, default values.

With more and more actual data on the energy efficiency of ships which are not covered by the regulatory MRV system being provided by shipping companies that claim subsidies by voluntary MRV, the energy efficiency database can be enriched by this data. Thereby the possible difference between the distribution of the energy efficiency of ships covered by the regulatory MRV and those that are not could be overcome. As ships outside the scope of MRV are not legally bound to provide the data regularly on an annual basis, they should be assigned the default energy efficiency if no actual value from the previous year is available. The lower the efficiency that the policymaker assumes in setting this default value, the greater is the incentive of shipping companies to voluntarily provide the missing data.

From this, it follows that the tax authorities will be provided with precise and largely verifiable data to determine the tax liability. Moreover, established and trusted data exchange mechanisms exist for the shipping companies to make claims for subsidies in an easily automatable form. Moreover, out of all competent authorities customs authorities are probably the ones that are most familiar with cross-country collaboration, having in place data transmission systems (and in the case of the Schengen area also integrated databases), which is not the case in most other fields of tax policy. By making customs authorities the body responsible for the implementation of the tax regime, the calculation of the provisional tax base using pre-existing systems comes at comparatively low additional cost and will be less likely held back by political games over data access rights.

\footnotetext{
${ }^{15}$ Such calculations are performed, for instance, by data providers such as www.dataloy.com.
} 


\subsection{Determining the tax base for intra-EU shipments}

When taxing emissions from international shipping, it is important to tax emissions from internal maritime shipping alike. Excluding the latter from an emissions tax would not compromise the environmental effectiveness of the tax, but it would raise concerns under WTO law. If the emissions tax regime described above is put in place without pricing also emissions released by vessels operating within EU waters, the compliance of the scheme with Art. III(2) GATT could be questioned (see Dominioni et al. (2018) for a detailed discussion of compliance with Art. III(2) GATT). In particular, discrimination could take place if the products transported by these (untaxed) vessels compete with products transported in international shipping. We hence describe in the following how emissions from domestic shipping could equally be taxed at the same rate as emissions from international shipping.

The main reason why we suggest using a different mechanism for intra-EU shipping is that an alternative, probably less administratively complex, solution is available. Using customs data also for the taxation of emissions from intra-EU shipments is possible but not optimal. In certain cases, customs authorities do raise data also on intra-EU shipments - even if domestic goods do not need to clear customs - since the status of the cargo as community goods needs to be demonstrated in various circumstances. But there are also situations in which this data is not raised by customs authorities, i.e. when vessels never leave EU waters and exclusively transport community goods. Then the tax base could not be determined. Furthermore, even where the data is raised to establish the status of cargo as community goods, there is no customs bill to which the emissions tax could be added. The intuition of the tax regime that we suggest for international shipping, however, is that established transactions and systems should be re-used to the greatest extent possible to keep system costs down. Accordingly, using the customs system to tax emissions for intra-EU trade seems less appealing than it is for emissions caused by trade of EU member states with the rest of the world.

By introducing a fuel tax on emissions from intra-EU shipping as suggested by Hemmings (2011) and Kågeson (2011), these issues could be circumvented. Under such a regime, the emissions are taxed upstream, meaning that they are taxed indirectly by taxing the fuels based on their carbon content. A fuel tax is simple to administer and to comply with (Calder 2015). However, unlike with our mechanism for international shipping, under a fuel tax the consignee (consignor) of the cargo cannot be the taxable entity. Instead, the vessel owner should be defined as the taxable entity. This is unproblematic for intra-EU shipping since here there are neither problems of jurisdiction (as the emissions are released within EU territorial waters) nor of multiple Bills of Lading (as the tax base is independent of the cargo origin). As for road motor fuels, making the vessel owner the taxable entity does not preclude organising the collection of the tax through withholding taxes at the level of the fuel supplier. Since marginal compliance and administration costs typically fall in the size of a tax base, the tax should be levied as far upstream as possible, such as at refuelling companies. Charging upstream is not a problem for the mitigation incentives as the price signal gets passed on to the ship. 
The weak point of a fuel tax for intra-EU shipping, however, is that it offers loopholes for tax avoidance - the very argument that has led us to disfavour such a tax in the case of international shipping. Yet, this Achilles heel would not nearly be as vulnerable in the case of intra-EU shipping as it is for international shipping. If the tax were levied throughout the EU, the opportunities for tax avoidance for vessels transporting goods within the EU would be limited. The only opportunity for avoiding the tax would be by leaving EU waters in order to refuel outside the geographical coverage of the fuel tax. Even then, accessing the high seas would not suffice for a domestic ship to completely avoid tax liability since if a vessel left EU waters for refuelling, it would automatically be covered by the above-described emissions tax on international shipping. This is because under existing EU customs laws, a domestic vessel leaving and re-entering the EU must register its cargo in the EU customs system, even if it transports EU cargo only, to have the EU status of the cargo redetermined. As a result, a domestic vessel leaving the EU in order to refuel elsewhere and thus avoiding the fuel tax would be covered under the customs-based tax on emissions arising from international transport.

Opportunities for tax avoidance by refuelling outside EU waters could also be limited by prohibiting the installation of refuelling platforms within the EU member state's EEZ. The sea area covered by the EEZ is so large that any remaining incentives for tax avoidance should be effectively reduced. The Netherlands, Belgium and Germany e.g. already use maritime spatial planning. The prohibition of floating refuelling platforms would only be an extension to this existing system.

Where two systems for computing a tax base co-exist, they can overlap. Thus, these systems would need to be safeguarded against double-taxation. For this purpose, deep-sea vessels that refuel in EU ports should be exempted from the fuel tax. This is because emissions from deep-sea vessels are already covered by the emissions tax. Hence they should not be taxed twice through a tax on their fuel consumption. Furthermore, vessels departing from the EU for international destinations are equally covered by the emissions tax and should thus be exempt from the fuel tax, too. The amount of tax-free refuelling by vessels leaving the EU should not be limited to the estimated quantity of fuel to be consumed on the remainder of the voyage outside EU waters. Any such limitations might compromise the EU share in the international bunkering business because refuelling quantities sufficient for more than one voyage is common practise, not just a potential tax-avoidance strategy.

However, if bunkering of tax-free fuel per eligible vessel should not be limited, emphasis has to be placed on which vessels are eligible to do so. Clearly, vessels not leaving EU waters after refuelling should not be entitled to tax-free bunkering. But leaving EU waters for a short distance only should not qualify vessels either in order to discourage tax avoidance through disguised round-trips. To be entitled to tax-free bunkering vessels should have to leave EU waters for a voyage long enough to just disincentivise fuel tourism. Ex ante, eligibility for tax-free bunkering should have to be proved by producing the relevant customs documents which indicate the next port of call and thus document that the vessel will travel outside EU waters for a long enough distance. Ex-post, this assertion could be verified through the AIS positioning system. 
Another form of overlaps could occur where domestic vessels that have already paid the fuel tax leave the EU for a nearby port, load cargo there, and subsequently reenter the EU. The consignee of these goods would then be liable to pay the emissions tax, passing some of the economic incidence of the emissions tax onto the vessel owner. As the latter, however, would already have paid for its emissions through the fuel tax, he would have to bear more than the intended tax burden. To correct for this over-taxation, the vessel owner would have to be allowed to demand a rebate on its previous fuel tax bill, accounting for the amount of emissions that were covered under the emissions tax.

\subsection{Defining different taxable entities in international and internal shipping}

Above we have argued that for the emissions tax applied to international shipping the taxable entity should be the consignee or consignor. Whereas, for the fuel tax applied to domestic shipping we have argued that the taxable entity should be the vessel owner. At a first glance, an observer might find this variation in the taxable entity discriminative in some way. Economically, such discrimination does not exist, however. Instead, this arrangement minimises the overall system costs.

Tax remittance invariance By the standard Tax Remittance Invariance (Jenkin 1871; Logue and Slemrod 2010), the costs that vessel owners, consignees, consignors and fuel suppliers bear as a result of the proposed taxes would be the same independently of whom is the taxable entity. This is because the agent on whom the tax burden is imposed will pass the same portion of it onto the other parties involved. For example, the shipping company will pass some of their fuel tax burden onto the consignees and consignors of the cargo. The same applies to the custom-based emissions tax in international shipping. If, for instance, the consignee of the cargo foresees to be charged additional costs associated with the cargo, he will pass it partially onto the shipping companies when negotiating freight rates. Again, the shipping company, which is thereby indirectly burdened by an emissions tax, will pass some of that cost onto its fuel suppliers. The extent to which each agent is able to pass the real incidence of the tax onto other agents is determined entirely by the market structure and the elasticities of demand and supply along the supply chain (Keen et al. 2011). Thus, the fact that ship owners have to remit the fuel tax, whilst consignees (consignors) have to remit the emissions tax, does not change the distribution of the tax incidence.

Minimising the cost burden of the tax regime The tax regimes we propose do not only render taxation of maritime emissions economically, legally and politically feasible. They also achive this by imposing only low compliance and administration costs on the involved entities.

Defining the consignor (consignee) for international shipping and the ship owner for internal shipping, respectively, as the taxable entity, minimises the overall cost burden. Paying a tax is associated with compliance costs (filling out forms, providing documents, etc.). These costs are not the same for all possible taxable entities. Thus, the taxable entity should always be the agent facing the least compliance costs. As a result, all agents will benefit because the agent who bears the legal tax liability 
will pass on not just part of the tax itself, but also part of the compliance costs. So if the agent with the lowest compliance costs is the taxable entity, also the economic incidence borne by all agents participating in the transaction will be reduced. This means that the legal tax liability is actually relevant for the economic incidence of the tax, but only in terms of the absolute, not the relative amount of the total tax burden.

For the customs-based emissions tax in international shipping, we have shown why the compliance costs are low for the consignee. This is because the consignee (consignor) is already the taxable entity for other custom-based charges on the same cargo. Adding one more item to the list of existing custom charges appears to cause lower compliance costs than establishing a completely new type of transaction between tax authorities and shipping companies. For internal shipping, the customs-based transaction does not exist and hence defining the consignee (consignor) as taxable entity would establish a whole new transaction and thus increase compliance costs. Adding a fuel tax to an existing fuel bill, however, causes only low compliance costs.

The second way in which the definition of the taxable entity could change the economic burden arising from the tax is through administration costs. The costs for the tax authorities in administering the tax payment vary in the taxpayer. The lower the administration costs, the higher the net revenue. As a result, government needs lower taxes (or lower borrowing) to raise the same public revenues. The parties involved could benefit therefrom directly through a lower tax rate, or indirectly as participants in economic life. In the case of a Pigouvian tax, the tax rate is set reflecting the external damage and should therefore not be varied in administration costs. Both effects would, however, reduce the net economic burden of the tax.

\subsection{Setting the tax rate}

The tax rate can be determined in two different ways. Either the EU sets a tax rate reflecting the damage inflicted on the EU only. Such a tax rate would imply a price of GHG emission much lower than the accounting prices for $\mathrm{CO}_{2}$ usually used by governments, since the latter are generally calculated as to mirror damages accruing to the whole world. For legal reasons, ${ }^{16}$ a tax rate set along these lines might legally be easier to maintain. Alternatively, the EU could set the tax rate according to the estimates of global damage caused, thereby achieving greater climate change mitigation effects. However, in this case accommodating expenditure policy, i.e. earmarking of tax revenues, might be necessary to ensure compliance with the United Nations Law of the Sea (UNCLOS) (Dominioni et al. 2018).

The nominal tax rate levied on emissions in international shipping should be equivalent to the implicit tax rate levied on fuels in internal shipping. I.e., if a tonne of GHG is taxed at a certain rate in the custom-based system, the fuel tax should be set based on its carbon content such that the implicit tax per tonne of $\mathrm{CO}_{2}$ released at the point of combustion will be the same. Keeping the nominal tax rate the same for the emissions from international and internal shipping is important both for Pigouvian considerations and for WTO compliance (Dominioni et al. 2018).

\footnotetext{
${ }^{16}$ For a discussion of the legal implications see Dominioni et al. (2018).
} 


\section{Conclusion}

Despite the availability of technical and operational measures to reduce greenhouse gas emissions from international maritime transport, these emissions are amongst the fastest-growing of any global industry. A key impediment to mitigation in this sector is the lack of taxation of maritime fuels. To provide the needed mitigation incentives, maritime emissions would need to be priced, but the introduction of such emissions pricing is plagued by problems of tax competition, legal constraints on extraterritorial policy action, data unavailability over emissions, and concerns for competitiveness and distortions of trade patterns. Given these constraints, the predominant view in the literature is that the introduction of emissions taxation in the maritime sector would require a unanimous international agreement. Such an international agreement has, however, not been forthcoming despite decades of negotiations. Since there does not appear to be a functional outside option that a coalition of early movers could embark upon even without a global agreement, climate action in this sector can be easily blocked. This gridlock in negotiations might be broken, however, if there does-counter the common wisdom-exist a credible mechanism for a coalition of the willing to price maritime emissions even in the absence of an international agreement. This article develops such a mechanism, proposing a feasible and cost-effective unilateral tax regime which takes account of the above-mentioned constraints. It consists of a cargo-based tax on emissions from international maritime transport which uses default values on ship efficiency combined with a subsidy for owners of more efficient vessels, and a fuel tax on emissions from domestic shipping. Through such a unilateral tax regime the currently prevailing grid-lock in international negotiations could be startled and a global agreement become more feasible to achieve.

Acknowledgements We thank Goran Dominioni, Beatriz Martinez-Romera, Arne Pieters, Michael Faure, Anselm Görres, Tobias Hlobil, Michael Klauser, and workshop participants at MIT, the 15th GCET, the 17th GCET, at the University of Hamburg, at Erasmus University Rotterdam, at the IMF, at the 2014 Transport \& Environment Bunker Fuel Workshop, at EALE 2015 and at ICPP 2015 who provided insight and expertise that greatly assisted the research. We furthermore wish to thank Ansgar Belke and Joscha Beckmann for their valuable support. We would also like to show our gratitude to Emma Aisbett, Richard Buxbaum, Robert Cooter, Jos Dings, Jasper Faber, Carolyn Fischer, Stefan Haas, Bill Hemmings, Per Kågeson, Heiko Kunst, John Maggs, Damien Meadows, Andrew Murphy, Ian Parry, Sotiris Raptis and Stephen Stretton for their comments on earlier versions of the manuscript.

Open Access This article is distributed under the terms of the Creative Commons Attribution 4.0 International License (http://creativecommons.org/licenses/by/4.0/), which permits unrestricted use, distribution, and reproduction in any medium, provided you give appropriate credit to the original author(s) and the source, provide a link to the Creative Commons license, and indicate if changes were made.

\section{References}

Bäuerle T, Graichen J, Meyer K, Seum S (2010) Integration of marine transport into the European emissions trading system. Tech. rep., Federal Ministry for the Environment Nature Conservation. Building and Nuclear Safety, Dessau 
Burger A (2014) Schätzung der Umweltkosten in den Bereichen Energie und Verkehr. Tech. rep., Federal Ministry for the Environment Nature Conservation. Building and Nuclear Safety, Dessau

Business for Social Responsibility (2015) Clean cargo working group carbon emissions accounting methodology. Tech. rep., BSR Clean Cargo Working Group. https://www.bsr.org/reports/BSR_CCW G_Carbon_Emissions_Methodology_2015.pdf

Calder J (2015) Administration of a US carbon tax. In: Parry I, Morris A, Williams R III (eds) Implementing a US carbon tax. Routledge, Abingdon

Cames M, Graichen V, Faber J, Nelissen D (2015) Greenhouse gas emission reduction targets for international shipping. Tech. rep., Federal Ministry for the Environment, Nature Conservation, Building and Nuclear Safety, Berlin. https://www.oeko.de/oekodoc/2241/2015-023-en.pdf

Coady D, Parry I, Sears L, Shang B (2016) How large are global fossil fuel subsidies? World Dev 91(11):11-27

Cosbey A, Droege S, Fischer C, Reinaud J, Stephenson J, Weischer L, Wooders P (2012) A Guide for the Concerned: Guidance on the elaboration and implementation of border carbon adjustment. Tech. rep., ENTWINED, Stockholm. http://www.iisd.org/library/guide-concerned-guidance-elaboration-and-im plementation-border-carbon-adjustment

de Cendra J (2006) Can emissions trading schemes be coupled with border tax adjustments? An analysis vis-à-vis WTO law. RECIEL 15(2):131-145

Demsetz H (1967) Toward a theory of property rights. AM ECON REV 57(2):347-59

Dominioni G, Heine D, Martinez Romera B (2018) Regional carbon pricing for international maritime transport: challenges and opportunities for global geographical coverage. World Bank Policy Research Working Paper Series

European Commission (2013) Considerations for the implementation of the eManifest. Tech. rep., European Commission, DG Taxation and Customs Union, Brussels. http://protect-group.org/assets/ Uploads/130916WorkingdoceManifestV1-0clear.pdf

Faber J, Boon B, Berk M, Den Elzen M, Olivier J, Lee D (2007) Aviation and maritime transport in a post 2012 climate policy regime. Tech. Rep. April 2007. Bilthoven, Netherlands Environmentl Assessment Agency

Faber J, Markowska A, Nelissen D, Davidson M, Eyring V, Cionni I, Selstad E, Kågeson P, Lee D, Buhaug $\varnothing$, Lindtsad H, Roche P, Humpries E, Rose N, Graichen J, Cames M, Schwarz W (2009) Technical support for European action to reducing Greenhouse Gas Emissions from international maritime transport. Tech. rep., CE Delft, Delft. http://cedelft.eu/publicatie/technical_support_for_european_action_ to_reducing_greenhouse_gas_emissions_from_international_maritime_transport/1005

Fischer C, Fox AK (2009) Comparing policies to combat emissions leakage: border tax adjustments versus rebates. J Environ Econ Manag 64(2):199-216

Friedrich R, Bickel P, Greßmann A, Droste-Franke B, Renn O, Maibach M, Thöne M (2007) Ökonomische Bewertung von Umweltschäden. Dessau

Fullerton D, Wolverton A (2005) The two-part instrument in a second-best world. J Public Econ 89(9):1961-1975

Heine D (2017) Causation of genuinely social costs: Pigou enabling Coase through the causation principles underlying environmental taxation. Rotterdam Institute of Law and Economics (RILE) Working Paper Series. https://ssrn.com/abstract=3076146

Heine D, Faure MG, Lan CC (2017a) Augmenting forest sustainability certificates with fiscal instruments. Rotterdam Institute of Law and Economics (RILE) Working Paper Series 2015(7). https://ssrn.com/ abstract $=2617815$

Heine D, Gäde S, Dominioni G, Martinez Romera B, Pieters A (2017b) A regional solution for a transnational problem? - A mechanism to unilaterally tax maritime emissions while satisfying extraterritoriality, tax competition and political constraints. Rotterdam Institute of Law and Economics (RILE) Working Paper Series. https://ssrn.com/abstract=2512747

Heitmann N, Khalilian S (2011) Accounting for carbon dioxide emissions from international shipping. Burden sharing under different UNFCCC allocation options and regime scenarios. Mar Policy 35:682-691

Hemmings B (2011) The CO2 Taxation Option for an EU Shipping Measure. https://ec.europa.eu/clima/ sites/clima/files/docs/0036/taxation_en.pdf

IEA OECD, OPEC (2011) An update of the G20 Pittsburgh and Toronto Commitments. Tech. rep., IEA, OPEC, OECD and World Bank, Cannes. http://www.oecd.org/env/49090716.pdf 
IMO (2014) Third IMO GHG Study 2014. Tech. rep., International Maritime Organization, London. http://www.imo.org/en/OurWork/Environment/PollutionPrevention/AirPollution/Documents/ ThirdGreenhouseGasStudy/GHG3ExecutiveSummaryandReport.pdf

IMO (2015) Note by the international maritime organization to the forty-seventh session of the subsidiary body for scientific and technological advice (SBSTA 47). https://unfccc.int/files/parties_observers/ submissions_from_observers/application/pdf/971.pdf

Ismer R, Neuhoff K (2007) Border tax adjustment: a feasible way to support stringent emission trading. Eur J Law Econ 24(2):137-164

Jenkin H (1871) On the principles which regulate the incidence of taxes. P ROY SOC EDINB A 7:618-631

Kågeson P (2009) Making international transport pay its climate bill. https://www.transportenvironment. org/publications/making-international-transport-pay-its-climate-bill

Kågeson P (2011) The financial implications of a Levy \& GHG Fund. Tech. rep., Centre for Transport Studies, Royal Institute of Technology (KTH), Stockholm. http://vti.diva-portal.org/smash/get/diva2: 669341/FULLTEXT01.pdf

Keen M, Parry I, Strand J (2011) Market-based instruments for international aviation and shipping as a source of climate finance. World Bank policy research working paper series. https://www.imf.org/external/np/ g20/pdf/110411a.pdf http://scholar.google.com/scholar?hl=en\&btnG=Search\&q=intitle:No+Title\#0

Keen M, Parry I, Strand J (2013) Planes, ships and taxes: charging for international aviation and maritime emissions. ECON POLICY 28(76):701-749

Kollamthodi S, Pueyo A, Gibson G, Narkeviciute R, Hawkes A, Cesbron S, Milnes R, Harries J, Zamparutti T, Hernandez G, Kaltsouni S, Vancauwenbergh S, Goldenman G, Pålsson C, Bengtsson N, Rydbergh T, Nilsson L, Krantz A, Weber K, Scarbrough T, Whall C, Green C, Hill J, Lee J, Noden R, Grebot B, Lindstad H (2013) Support for the impact assessment of a proposal to address maritime transport greenhouse gas emissions. Tech. rep., Ricardo-AEA, Oxford. http://ec.europa.eu/clima/polic ies/transport/shipping/docs/ghg_maritime_report_en.pdf

Logue K, Slemrod J (2010) Of coase, calabresi, and optimal tax liability. Tax L Rev 63(4):797-866

Mazraati M (2011) Challenges and prospects of international marine bunker fuels demand. OPEC Energy Rev 35(1):1-26

Miola A, Marra M, Ciuffo B (2011) Designing a climate change policy for the international maritime transport sector: Market-based measures and technological options for global and regional policy actions. Energy Policy 39:5490-5498. http://ac.els-cdn.com/S0301421511003855/1-s2.0-S03014215110038 55/1-s2.0-S0301421511003855-main.pdf?_tid=238e83ec-313f-11e4-8936-00000aab0f27_acdnat=140 9510977_e207164f6c834d1cdc5d84ca97e1cb22

Mishra GS, Yeh S (2011) Inclusion of marine bunker fuels in a national LCFS scheme. Tech. Rep. May, Universitiy of California, Davis, Davis, California. https://s3.amazonaws.com/academia.edu.documents/ 44229724/Inclusion_of_Marine_Bunker_Fuels_in_a_Na20160330-19063-10xz1j2.pdf?AWSAccessKey Id=AKIAIWOWYYGZ2Y53UL3A\&Expires=1510776263\&Signature=y8iyAHagyFmckAuJP4vyW tjkzS0\%3D\&response-content-disposition=inline

Oberthür S (2003) Institutional interaction to address greenhouse gas emissions from international transport: ICAO, IMO and the Kyoto Protocol. CLIM POLICY 3(3):191-205

Parry I, Heine D, Lis E, Li S (2014) Getting energy prices right: From principles to practice. International Monetary Fund, Washington DC

Pigou A (1932) The economics of welfare. Macmillan, London

Price R, Thornton S, Nelson S (2007) The social cost of carbon and the shadow price of carbon: What they are, and how to use them in economic appraisal in the UK. Tech. Rep. December, Department for Environment, Food and Rural Affairs, London. https://www.gov.uk/government/uploads/system/ uploads/attachment_data/file/243825/background.pdf

Schwermer S (2012) Methodenkonvention 2.0 zur schätzung von Umweltkosten. Tech rep. Umweltbundesamt, Dessau

Scott J (2014) Extraterritoriality and territorial extension in EU law. Am J Comp L 62:87-126

Shih WC (2011) The border tax adjustment provisions of the GATT/WTO and their implications on the design of energy and carbon tax. International Trade and Business Law Review 14:53-84

Sims R, Schaeffer R, Creutzig F, Cruz-Núñez X, D’Agosto M, Dimitriu D, Figueroa Meza MJ, Fulton L, Kobayashi S, Lah O, McKinnon A, Newman P, Ouyang M, Schauer J, Sperling D, Tiwari G (2014) Climate change 2014: Mitigation of climate change, Chapter 8 - Transport. Tech. rep., Geneva. https:// ipcc.ch/report/ar5/wg3 
Stiglitz JE (2006) A new agenda for global warming. The Economists' Voice 3. https://doi.org/10.7916/D8 XD1BHS

Trachtman JP (2016) WTO law constraints on border tax adjustment and tax credit mechanisms to reduce the competitive effects of carbon taxes. Resources for the Future Discussion Paper Series 2016(03). http://www.rff.org/files/document/file/RFF-DP-16-03.pdf

US-IAWG (2013) Technical update of the social cost of carbon for regulatory impact analysis under executive order 12866. Tech. rep., Interagency Working Group on Social Cost of Carbon, United States Government, Washington DC. http://www.whitehouse.gov/sites/default/files/omb/assets/inforeg/technicalupdate-social-cost-of-carbon-for-regulator-impact-analysis.pdf

Wilensky M (2014) Authority of pacific island states to regulate greenhouse gases from the international shipping sector. Tech. rep., Columbia Law School, Center for Climate Change Law, New York. http://wordpress.ei.columbia.edu/climate-change-law/files/2016/06/Wilensky-2014-02-Pacific-IslandShipping-GHG-Regulation-.pdf 